\title{
PENGARUH ON TIME PERFORMANCE TERHADAP MINAT BELI ULANG PADA PT. GARUDA INDONESIA (PERSERO) TBK
}

\author{
Yunika Dortina ${ }^{1}$, Devi Roza K. Kausar ${ }^{2}$, Yustisia Pasfatima Mbulu ${ }^{3}$ yunikadortina@gmail.com \\ Program Studi Pariwisata Fakultas Pariwisata Universitas Pancasila Jl. Srengseng Sawah, Jagakarsa, \\ Jakarta Selatan $12640{ }^{1}$ Mahasiswa S1 Pariwisata, ${ }^{2 \& 3}$ Dosen Pembimbing I \& II
}

\begin{abstract}
ABSTRAK
Penelitian ini dilakukan untuk mengetahui pengaruh On Time Performance terhadap Minat Beli Ulang pada PT. Garuda Indonesia (Persero) Tbk. Manajemen atau program yang dilakukan maskapai penerbangan Garuda Indonesia untuk memaksimalkan kinerja dalam bidang ketepatan waktu (On Time Performance) sudah sangat baik dan maksimal. Garuda Indonesia sangat memperhatikan kepuasan pelanggan sehingga menciptakan program dari Garuda Indonesia tersebut yang sudah sangat lengkap sehingga meminimalisir adanya delay atau keterlambatan. Hasil temuan pengaruh On Time Performance pada PT. Garuda Indonesia (Persero) Tbk. Pada minat beli ulang konsumen yaitu sebesar 32\% yang artinya bahwa variable On Time Performance berkorelasi positif dengan variabel Minat Beli Ulang, dengan tingkat hubungan sedang. Dari segi On Time Performance menjadi alasan utama konsumen mempunyai minat beli ulang, dapat dilihat bahwa On Time Performance bukan menjadi satu-satunya alasan komsumen membeli ulang jasa penerbangan Garuda Indonesia. Beberapa faktor atau alasan lain konsumen mempunyai minat beli ulang pada maskapai Garuda Indonesia adalah Pelayanan, Fasilitas, Pengalaman.
\end{abstract}

Kata Kunci: On Time Performance, Minat Beli Ulang, Garuda Indonesia.

\section{PENDAHULUAN}

\section{Latar Belakang}

Industri pariwisata sangatlah terkait dengan pengangkutan atau transportasi. Transportasi yang memadai merupakan salah satu komponen aksesibilitas bagi destinasi pariwisata. Di era globalisasi seperti sekarang ini kebutuhan akan sarana transportasi yang nyaman, murah dan cepat sangat dibutuhkan oleh setiap orang dan transportasi yang cukup populer bagi mereka yang membutuhkan efisiensi waktu dan kenyamanan adalah pesawat terbang. Industri penerbangan di Indonesia sendiri cukup pesat, ditandai dengan banyaknya penerbangan domestik maupun internasional, banyaknya maskapai- maskapai penerbangan baru dan bertambahnya Bandar Udara (Bandara) di berbagai daerah di Indonesia

PT. Garuda Indonesia (Persero) Tbk. berkomitmen untuk menyediakan layanan yang luar biasa bagi para penumpang PT. Garuda Indonesia (Persero) Tbk. Untuk mewujudkan komitmen ini, PT. Garuda Indonesia (Persero) Tbk. telah menjalin dan mengembangkan kerjasama dengan berbagai perusahaan dan organisasi misalnya Liverpool FC. Program ini akan mengubah Garuda Indonesia menjadi perusahan global.

Pada tahun 2016, pertumbuhan trafik penumpang Perseroan secara total masih mengalami pertumbuhan sebesar 6,19\% dibandingkan periode sebelumnya. Peningkatan jumlah penumpang ini disebabkan oleh beberapa faktor. Salah satu faktornya adalah On Time Performance.

On Time Performance merupakan unsur yang terkait dalam dunia penerbangan yang mengakibatkan loyalitas konsumen terhadap suatu produk jasa. Jika maskapai mengalami keterlambatan pada pesawat bisa menjadi salah satu alasan penumpang tidak ingin menggunakan maskapai tersebut. Dalam kaitannya dengan hal tersebut maka On Time Performance harus diunggulkan dan lebih 
baik lagi agar dapat menarik minat para penumpang.

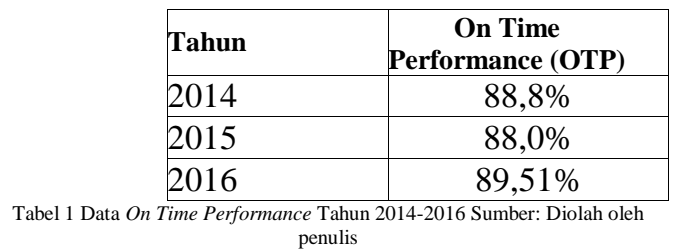

Berdasarkan tabel di atas adapun tingkat ketepatan penerbangan (On Time Performance/OTP) pada tahun 2015 mencapai $88,0 \%$, sedikit menurun dibandingkan tahun sebelumnya sebesar $88,8 \%$. Hal ini antara lain dipengaruhi oleh terjadinya force majeure seperti erupsi gunung berapi dan kabut asap akibat kebakaran hutan sepanjang tahun 2015 yang menyebabkan pembatalan penerbangan dari dan ke sejumlah bandara di Jawa dan Bali. Tetapi, pada tahun 2016 Garuda Indonesia dapat memperbaiki hal tersebut. Terbukti pada tahun 2016 On Time Performance yang diraih meningkat yaitu menjadi $89,51 \%$.

Suzuki (1999) mengatakan bahwa On Time Performance mempengaruhi market share di suatu maskapai penerbangan. Sedangkan menurut Prince dan Simon (2014), persaingan dari maskapaimaskapai baru seringkali menyebabkan performa $\mathrm{On}$ Time Performance maskapai lama menurun karena mengahlihkan aspek On Time Performance untuk aspek-aspek lainnya agar dapat bersaing dengan maskapai baru, sehingga performa dari On Time Performance maskapai lama menurun.

Berdasarkan uraian diatas, maka penulis tertarik untuk mengkaji lebih dalam dan mengemukakan sebuah skripsi atau karya ilmiah dengan judul Pengaruh On Time Performance Terhadap Minat Beli Ulang pada PT. Garuda Indonesia (Persero) Tbk.

\section{TINJAUAN PUSTAKA}

\section{Pengertian Transportasi}

Transportasi saat ini berperan sangat penting dalam memindahkan manusia maupun barang. Karena dengan transportasi dapat memberikan kemudahan aktivitas bagi manusia, serta dengan adanya transportasi dapat membantu menunjang perkembangan ekonomi suatu negara. Transportasi itu sendiri dapat di definisikan sebagai berikut, Menurut Abbas Salim (2016:6) transportasi adalah kegiatan pemindahan barang (muatan) dan penumpang dari suatu tempat ke tempat lain. Dalam transportasi ada dua unsur yang terpenting yaitu:

a. Pemindahan atau pergerakan (movement).

b. Secara fisik mengubah tempat dari barang (komoditi) dan penumpang ke tempat lain.

\section{Sifat dan Karakteristik Angkutan Udara}

Pelaku Pariwisata adalah setiap pihak yang Menurut Nasution (2015:205-206) sifat dan karakteristik umum jasa angkutan udara adalah sebagai berikut:

a Produksi yang dihasilkan tidak dapat disimpan dan dipegang tetapi dapat di tandai dengan adanya pemanfaatan waktu dan tempat. Unit produksi adalah seat $/ \mathrm{km}$ tersedia dan ton $/ \mathrm{km}$ tersedia. Seat $/ \mathrm{km}$ tersedia (available seat $/ \mathrm{km}$ ) adalah satu seat yang diterbangkan dalam jarak satu kilometer. Ton $/ \mathrm{km}$ tersedia adalah satu ton barang dalam satu kilometer. Bila seat $/ \mathrm{km}$ tersedia dan ton $/ \mathrm{km}$ tersedia telah digunakan users, maka produksi tersebut menjadi revenue passanger $/ \mathrm{km}$ dan revenue cargo $/ \mathrm{km}$.

b. Permintaan bersifat elastis. Permintaan jasa angkutan udara bersifat derived demand, yaitu sebagai akibat adanya permintaan atau kebutuhan di lokasi lain. Karena tarif angkutan udara relatif mahal, maka bila terjadi perubahan harga, maka permintaan menjadi elastis.

c. Selalu menyesuaikan dengan teknologi maju. Perusahaan penerbangan pada dasarnya bersifat dinamis, yang dengan cepat menyesuaikan perkembangan teknologi pesawat udara. Penyesuaian teknologi maju tidak hanya di bidang teknik permesinan pesawat terbang saja, tetapi juga di bidang-bidang lainnya, seperti sistem informasi manajemen, metode-metode, peraturan-peraturan dan prosedur, serta kebijakan.

\section{Pengertian On Time Performance}

On Time Performance mempunyai arti bahwa penerbangan berangkat sesuai dengan jadwal yang ditentukan. Menurut Nasr (2008:116) on time performance adalah catatan dari ketepatan waktu perusahaan penerbangan 
pada keberangkatan dan kedatangan penerbangan. Ketepatan waktu dalam satu periode (bulan atau tahun) merupakan penampilan dan keseluruhan ketepatan waktu.

Faktor-faktor tidak tercapainya On Time Performance menurut Hadi Mulyanto (1999:13), meliputi:

\section{Ramp Handling}

Muatan dan pos, dokumen pesawat terbang, refueling, catering, kerusakan pada waktu boarding, pembersihan pesawat.

2. Terminal Handling

Check-In terlambat, VIP, Penanganan Group passenger yang bermasalah, oversales, penyelesaian bagasi.

3. Operational Handling

Adanya perubahan atau masalah pada dokumentasi penerbangan, penumpang yang bermasalah dengan tiketnya, sistem data atau computer check-in rusak atau hang.

4. Technical Problem

Pesawat terlambat keluar dari hangar, kerusakan pada pesawat, spares atau peralatan yang kurang, penggantian pesawat (karena alas an teknis).

5. Extern

Cuaca, masalah pada imigrasi dan pabean, airport security, crew pesawat yang terlambat serta fasilitas bandara yang bermasalah.

\section{Pengertian Minat Beli Ulang (Repurchase Intention)}

Menurut Lucas \& Britt (2012), terdapat empat faktor yang mempengaruhi minat beli konsumen, antara lain:

a. Perhatian (Attention) Adanya perhatian yang besar dari konsumen terhadap suatu produk (barang atau jasa).

b. Ketertarikan (Interest) Menunjukkan adanya pemusatan perhatian dan perasaan senang.

c. Keinginan (Desire) Adanya dorongan untuk ingin memiliki.

d. Keyakinan (Conviction) Adanya perasaan percaya diri individu terhadap kualitas, daya guna, dan keuntungan dari produk yang akan dibeli.

Menurut Thamrin dan Francis (2012), minat beli ulang merupakan minat pembelian yang didasarkan atas pengalaman pembelian yang telah dilakukan dimasa lalu. Minat beli ulang yang tinggi mencerminkan tingkat kepuasan yang tinggi dari konsumen ketika memutuskan untuk mengadopsi suatu produk. Keputusan untuk mengadopsi atau menolak suatu produk timbul setelah konsumen mencoba suatu produk tersebut dan kemudian timbul rasa suka atau tidak suka terhadap produk tersebut. Rasa suka terhadap produk timbul bila konsumen mempunyai persepsi bahwa produk yang mereka gunakan berkualitas baik dan dapat memenuhi atau bahkan melebihi keinginan dan harapan konsumen. Dengan kata lain produk tersebut mempunyai nilai yang tinggi di mata konsumen. Tingginya minat beli ulang ini akan membawa dampak yang positif terhadap keberhasilan produk di pasar.

\section{Dimensi Minat Beli Ulang}

Menurut Ferdinand (2002) minat beli ulang dapat diidentifikasikan melalui indikatorindikator sebagai berikut:

1. Minat Transaksional, yaitu kecenderungan seseorang untuk membeli ulang produk yang telah dikonsumsinya.

2. Minat Referensial, yaitu kecenderungan seseorang untuk mereferensikan produk yang sudah dibelinya, agar juga dibeli orang lain dengan referensi pengalaman konsumsinya.

3. Minat Preferensial, yaitu minat yang menggambarkan perilaku sesorang yang selalu memiliki preferensi utama pada produk yang telah dikonsumsinya, preferensi ini hanya dapat diganti bila terjadi sesuatu dengan produk referensinya.

4. Minat Eksploratif, yaitu minat yang menggambarkan perilaku seseorang yang selalu mencari informasi mengenai produk yang diminatinya dan mencari informasi utnuk mendukung sifat-sifat positif dari produk yang ditanganinya.

\section{METODOLOGI PENELITIAN}

Metode penelitian yang digunakan dalam penelitian ini adalah metode analisis kuantitatif, yaitu penelitian yang menekankan analisisnya pada data numerical atau angka yang diperoleh dengan metode statistik serta dilakukan pada penelitian inferensial atau dalam rangka pengujian hipotesis sehingga 
diperoleh signifikansi hubungan antara variabel yang diteliti. Sugiyono (2011) mengemukakan sebagai berikut: Penelitian kuantitatif dapat diartikan sebagai metode penelitian yang berlandaskan pada filsafat positivism, digunakan untuk meneliti pada populasi atau sampel tertentu, pengumpulan data menggunakan instrumen penelitian, analisis data bersifat kuantitatif/statistik, dengan tujuan untuk menguji hipotesis.

Berdasarkan pemaparan di atas, dapat disimpulkan bahwa pendekatan kuantitatif merupakan suatu pendekatan di dalam penelitian untuk menguji hipotesis dengan menggunakan uji data statistik yang akurat. Berdasarkan latar belakang dan rumusan masalah yang telah disebutkan, penelitian ini menggunakan pendekatan kuantitatif untuk mengukur pengaruh on time performance terhadap minat beli ulang pada maskapai Garuda Indonesia.

\section{HASIL DAN PEMBAHASAN}

\section{Gambaran Umum Perusahaan}

Sejarah PT. Garuda Indonesia (Persero) Tbk: seiring semakin meningkatnya permintaan jasa industri penerbangan, Perusahaan terus mengembangkan jaringan penerbangan hingga ke kota-kota pertumbuhan ekonomi dan wisata baru di wilayah Barat dan Timur Indonesia. Sejarah penerbangan komersial Indonesia dimulai saat bangsa Indonesia sedang mempertahankan kemerdekaannya. Penerbangan komersial pertama menggunakan pesawat DC-3 Dakota dengan registrasi RI 001 dari Calcutta ke Rangoon dan diberi nama "Indonesian Airways" dilakukan pada 26 Januari 1949. Pada tahun yang sama, 28 Desember 1949, pesawat tipe Douglas DC-3 Dakota dengan registrasi PK- DPD dan sudah dicat dengan logo "Garuda Indonesian Airways", terbang dari Jakarta ke Yogyakarta untuk menjemput Presiden

Soekarno. Inilah penerbangan yang pertama kali dengan nama Garuda Indonesian

Airways. Nama "Garuda" diberikan oleh Presiden Soekarno dimana nama tersebut diambil dari sajak Belanda yang ditulis oleh penyair terkenal pada masa itu, Noto Soeroto; "Ik ben Garuda, Vishnoe's vogel, die zijn vleugels uitslaat hoog bovine uw einladen", yang artinya, "Saya Garuda, burung Vishnu yang melebarkan sayapnya tinggi di atas kepulauan Anda".

\section{Manajemen Program On Time Performance di PT. Garuda Indonesia (Persero) Tbk.}

Kita perlu mengetahui bagaimana cara atau manajemen dari PT. Garuda Indonesia (Persero) Tbk dalam mengelola agar suatu penerbangan selalu tepat waktu (On Time Performance). Dari pihak Garuda Indonesia sendiri telah memberitahu bagaimana manajemen mereka dalam mempertahankan On Time Performance. Program kerja Operasi dan Keselamatan Penerbangan yang dijalankan adalah:

1. Improve Operations Monitoring \& Control by Integrated Operational Control System (IOCS): Pemantauan terhadap keterlambatan penerbangan (delay) terutama ditujukan pada penyebab delay terbesar (teknik, flight operations, dan airport facilities) untuk kemudian dimintakan solusi dari unitunit organisasi yang terkait.

2. On Time Performance Enhancement Program.

3. Develop Operational Data, Information and Publication: membangun data yang mendukung analisa penggunaan fuel, beban fuel dan membuat format digital (pdf) Aircraft Operations Manual (AOM).

4. Control Flight Operation Cost: dengan menjalankan program efisiensi yang meliputi Fuel Conservation, Centralized Flight Planning, Optimasi Route Database Jeppesen.

5. Optimazion of Crew Schedule and Crew Positioning: optimasi Crew Rotation Pattern (CROPA) yang antara lain dapat mengurangi extra crew, pembandingan antara standar awak kabin (flight attendant) dan kebutuhan.

6. Optimalization of Cockpit Crew Resources melalui kerjasama operasi dengan beberapa maskapai penerbangan untuk menyediakan pilot.

7. Implement Flight Attendant Performance Standard berupa pengembangan standar bahasa Inggris, Cina, Jepang, dan Korea bagi awak kabin serta menyusun desain baru silabus Safety Emergency Procedure untuk awak kabin.

8. Improve Flight Attendant Performance melalui Service Recurrent Training. 
9. Continuous Improvement of Safety Management System: safety risk \& hazard telah di masukkan ke dalam Safety Management System.

10. Continuous Improvement of Emergency Response Plan (ERP) melalui ERP training untuk Kepala Stasiun (Station Manager).

11. Continuous Improvement of Environment Program melalui penyempurnaan dan sosialisasi Health, Safety and Environment (HSE) manual.

12. Safety Audit Program termasuk menindak lanjuti audit finding dan memantaunya.

13. Corporate Quality System: Corporate Quality Manual telah disampaikan kepada para Department Quality Manager untuk kemudian disosialisasi.

14. Quality of Inspection Improvement dengan meningkatkan pelaksanaan surveilance dan ramp check di lapangan/apron.

15. Enhance Technical Ground Handling dengan memberikan kursus singkat kepada para Technical Handling personil.

16. Enhance Maintenance Planning \& Control dengan meningkatkan pengendalian pada aircraft assigmentdan maintenance Turn Around Time di hanggar.

17. Enhance On Line Monitoring \& Control dengan peningkatan Aircraft Communication Addressing and Reporting System (ACARS) dan Engine Trend Monitoring.

18. Enhance Leadership \& Managing Line Operation dengan melaksanakan kursuskursus supervisor bagi supervisor maintenance di GMF.

19. Melaksanakan C-check dan D-check sejumlah 32 pesawat untuk menjaga kondisi pesawat tetap terawat dengan baik, serta meningkatkan kehandalan atau performance serta ketersediaan atau availability pesawat.

Menurut Asad Y Nasr (2008:116) On Time Performance adalah catatan dari ketepatan waktu perusahaan penerbangan pada keberangkatan dan kedatangan penerbangan. Dalam program yang dilakukan maskapai penerbangan Garuda Indonesia untuk memaksimalkan kinerja dalam bidang ketepatan waktu (On Time Performance) sudah sangat baik dan maksimal, dimana PT. Garuda Indonesia memperhatiakan dari segala bidang, yaitu: Ramp Handling, Terminal Handling, Operational Handling, Technical Problem, Eksterns. Program dari Garuda Indonesia tersebut sudah sangat lengkap sehingga meminimalisir adanya delay atau keterlambatan

\section{Karakteristik Responden}

Penelitian ini menggunakan random sample. Dengan kriteria responden adalah pengguna jasa penerbangan PT. Garuda Indonesia (Persero) Tbk. Analisa terhadap karakteristik responden di kelompokan menjadi usia, jenis kelamin, pekerjaan, penghasilan, menggunakan jasa penerbangan Garuda Indonesia dalam 6 bulan terakhir, jumlah penggunaan jasa penerbangan Garuda Indonesia dalam 6 bulan terkahir. Profil responden akan disajikan pada diagram berikut:

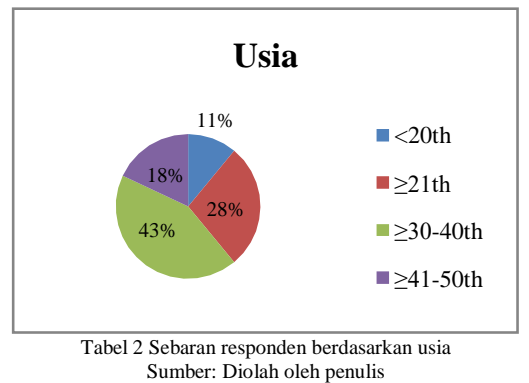

Berdasarkan tabel 2 dapat dilihat bahwa persentase pengguna jasa PT. Garuda Indonesia (Persero) Tbk berusia $\geq 30-40$ tahun berjumlah 43 responden dengan persentase sebesar $43 \%$, lalu responden yang berusia $\geq 21$ tahun berjumlah 28 responden dengan persentase sebesar $28 \%$, kemudian responden yang berusia $\geq 41-50$ tahun berjumlah 18 responden dengan persentase $18 \%$, dan yang berusia $<20$ tahun berjumlah 11 responden dengan persentase $11 \%$. Jadi dapat disimpulkan bahwa pengguna jasa PT. Garuda Indonesia (Persero) Tbk mayoritas responden berusia $\geq 30-40$ tahun dengan jumlah 43 responden dengan persentase $43 \%$. 


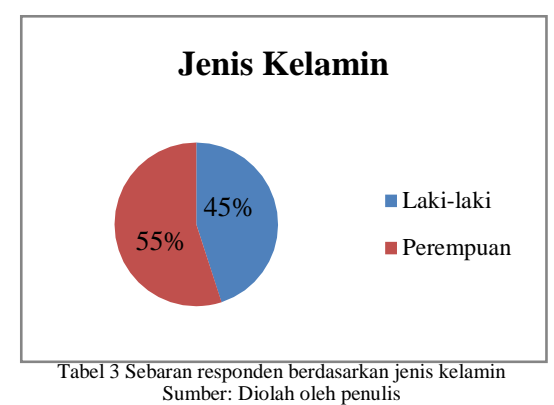

Berdasarkan tabel 3 dapat dilihat bahwa persentase pengguna jasa PT. Garuda Indonesia (Persero) Tbk adalah laki-laki berjumlah 45 responden dengan persentase $45 \%$ dan perempuan berjumlah 55 responden dengan persentase 55\%. Jadi dapat disimpulkan bahwa pengguna jasa PT. Garuda Indonesia (Persero) Tbk mayoritas responden berjenis kelamin perempuan dengan jumlah 55 responden dengan persentase $55 \%$.

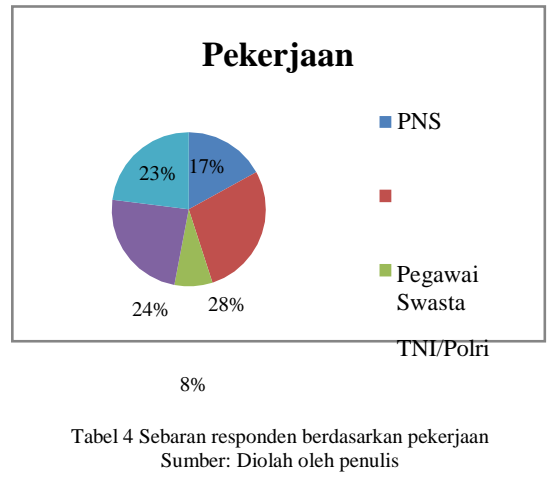

Berdasarkan tabel 4 dapat dilihat bahwa persentase pekerjaan pengguna jasa PT. Garuda Indonesia (Persero) Tbk adalah pegawai swasta berjumlah 28 responden dengan persentase $28 \%$, lalu pekerjaan responden wiraswasta berjumlah 24 responden dengan persentase $24 \%$, lalu pekerjaan responden lainnya berjumlah 23 responden dengan persentase $23 \%$, kemudian pekerjaan responden PNS berjumlah 17 responden dengan persentase $17 \%$, dan pekerjaan responden TNI/Polri berjumlah 8 responden dengan persentase $8 \%$. Jadi dapat disimpulkan bahwa pekerjaan pengguna jasa PT. Garuda Indonesia (Persero) Tbk mayoritas responden adalah pegawai swasta dengan jumlah 28 responden dengan persentase $28 \%$.

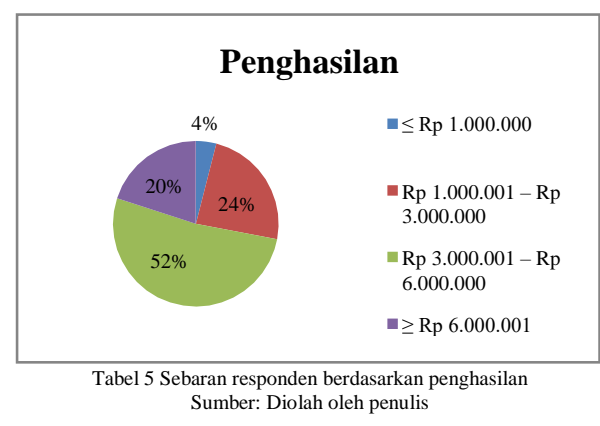

Berdasarkan tabel 5 dapat dilihat bahwa penghasilan pengguna jasa PT. Garuda Indonesia (Persero) Tbk berjumlah Rp 3.000 .001 - Rp 6.000 .000 berjumlah 52 responden dengan persentase $52 \%$, lalu penghasilan responden berjumlah $\mathrm{Rp}$ 1.000.001 - Rp 3.000.000 dengan jumlah 24 responden dengan persentase $24 \%$, kemudian penghasilan responden $\geq \mathrm{Rp} 6.000 .001$ dengan jumlah 20 responden dengan persentase $20 \%$, dan penghasilan responden $\leq$ Rp 1.000.000 dengan jumlah 4 responden dengan persentase $4 \%$. Jadi dapat disimpulkan bahwa penghasilan pengguna jasa PT. Garuda Indonesia (Persero) Tbk mayoritas responden berjumlah Rp 3.000.001 - Rp 6.000.000 berjumlah 52 responden dengan persentase $52 \%$.

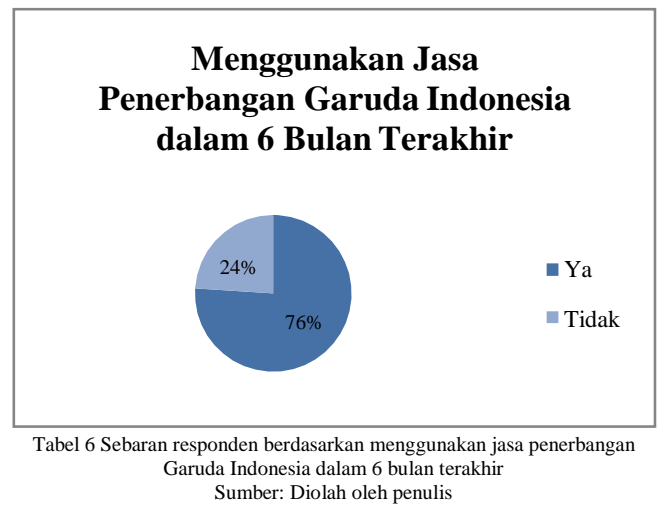

Berdasarkan tabel 6 dapat dilihat bahwa pengguna jasa penerbangan PT. Garuda Indonesia (Persero) Tbk dalam 6 bulan terakhir yang menggunakan berjumlah 76 responden dengan persentase $76 \%$ dan yang tidak menggunakan jasa penerbangan PT. Garuda Indonesia (Persero) Tbk dalam 6 bulan terakhir berjumlah 24 responden dengan jumlah persentase $24 \%$. Jadi dapat disimpulkan bahwa responden yang menggunakan jasa PT. Garuda Indonesia (Persero) Tbk dalam 6 bulan terakhir 
mayoritas responden berjumlah 76 responden dengan persentase $76 \%$.

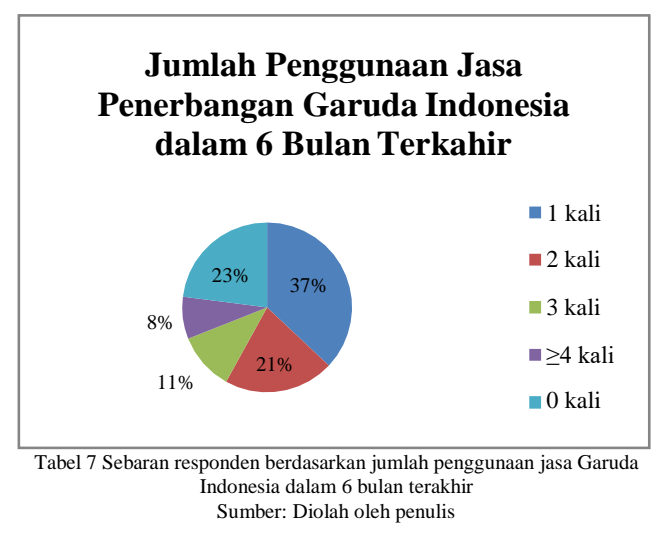

Berdasarkan tabel 7 dapat dilihat bahwa jumlah penggunaan jasa penerbangan PT. Garuda Indonesia (Persero) Tbk dalam 6 bulan terakhir berjumlah 1 kali penggunaan berjumlah 37 kali dengan persentase $37 \%$, lalu berjumlah 0 kali penggunaan berjumlah

23 responden dengan persentase $23 \%$, lalu berjumlah 2 kali penggunaan berjumlah 21 responden dengan persentase $21 \%$, kemudian berjumlah 3 kali penggunaan berjumlah 11 penggunaan dengan persentase, dan berjumlah $\geq 4$ kali penggunaan berjumlah 8 responden dengan persentase $8 \%$. Jadi dapat disimpulkan bahwa jumlah penggunajasa PT. Garuda Indonesia (Persero) Tbk dalam 6 bulan terakhir mayoritas responden berjumlah 1 kali penggunaan berjumlah 37 kali dengan persentase $37 \%$.

\section{Analisis Hasil Penelitian On Time Performance (Variable X)}

Penulis membuat penjabaran variable $\mathrm{X}$ (On Time Performance) ke dalam indikator untuk membuat suatu kuesioner, dimana dapat dilihat dalam berikut ini:

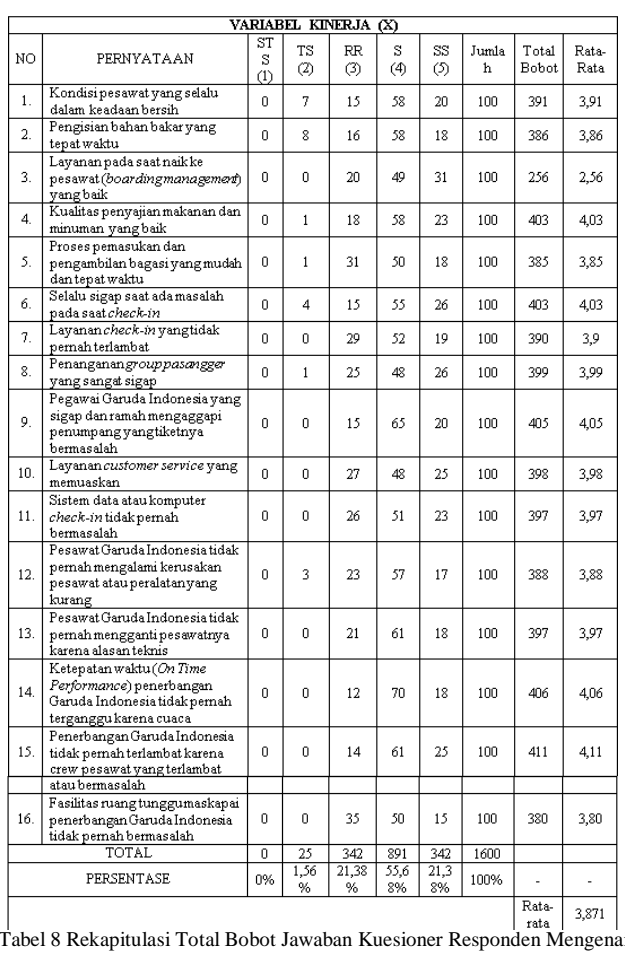

On Time Performance $(\mathrm{X})$

Dari rekapitulasi data pada table 8 variabel On Time Performance (X) diatas dapat dikatakan bahwa jumlah responden yang menjawab 16 butir pernyataan dari variabel On Time Performace (X) yang memilih sangat setuju (SS) yaitu 342 responden atau sebesar 21,38\%, setuju (S) yaitu 891 responden atau sebesar 55,68\%, ragu-ragu (RR) yaitu 342 atau sebesar $21,38 \%$, tidak setuju (TS) yaitu 25 responden atau sebesar $1,56 \%$, dan sangat tidak setuju (STS) yaitu 0 responden atau sebesar $0 \%$.

Kriteria Penelitian Berdasarkan Weight Mean Scored:

\begin{tabular}{|l|l|}
\hline Interval & Kriteria \\
\hline $1,00-1,80$ & Sangat Tidak Baik \\
\hline $1,81-2,60$ & Tidak Baik \\
\hline $2,61-3,40$ & Cukup Baik \\
\hline $3,41-4,20$ & Baik \\
\hline $4,21-5,00$ & Sangat Baik \\
\hline \multicolumn{2}{|c|}{ Tabel 9 Kriteria Penilaian } \\
Sumber: Siregar (2012)
\end{tabular}

Berdasarkan tabel 9 untuk variabel On Time Performance(X), menunjukkan bahwa ratarata pernyataan sebesar 3,871 dengan kriteria baik. 
Dengan respon rata-rata baik dari responden untuk On Time Performance $(\mathrm{X})$ pada maskapai penerbangan Garuda Indonesia, menandakan bahwa responden setuju bahwa maskapai penerbangan Garuda Indonesia mempunya performa ketepatan waktu yang baik.

a. $\quad$ Uji Validitas Variabel On Time Performance (X) Penulis melakukan uji validitas dengan bantuan software SPSS versi 21. Berikut ini merupakan hasil uji validitas dan uji reabilitas variabel On Time Performance (X):

\begin{tabular}{|c|c|c|c|c|c|}
\hline Variabel & $\begin{array}{c}\text { Item } \\
\text { Kuesioner }\end{array}$ & $\begin{array}{c}\text { Pearson } \\
\text { Corellation } \\
\text { (r Hitung }\end{array}$ & Signifikansi & rTabel & Keterangan \\
\hline \multirow{16}{*}{$\begin{array}{c}\text { On Time } \\
\text { Performance } \\
\text { (X) }\end{array}$} & 1 & 0,519 & 0,000 & 0,165 & Valid \\
\hline & 2 & 0,541 & 0,000 & 0,165 & Valid \\
\hline & 3 & 0,591 & 0,000 & 0,165 & Valid \\
\hline & 4 & 0,347 & 0,000 & 0,165 & Valid \\
\hline & 5 & 0,393 & 0,000 & 0,165 & Valid \\
\hline & 6 & 0,488 & 0,000 & 0,165 & Valid \\
\hline & 7 & 0,383 & 0,000 & 0,165 & Valid \\
\hline & 8 & 0,505 & 0,000 & 0,165 & Valid \\
\hline & 9 & 0,318 & 0,001 & 0,165 & Valid \\
\hline & 10 & 0,501 & 0,000 & 0,165 & Valid \\
\hline & 11 & 0,321 & 0,001 & 0,165 & Valid \\
\hline & 12 & 0,533 & 0,000 & 0,165 & Valid \\
\hline & 13 & 0,350 & 0,000 & 0,165 & Valid \\
\hline & 14 & 0,362 & 0,000 & 0,165 & Valid \\
\hline & 15 & 0,542 & 0,000 & 0,165 & Valid \\
\hline & 16 & 0,296 & 0,000 & 0,165 & Valid \\
\hline
\end{tabular}

Tabel 10 Hasil Uji Validitas Variabel On Time Performance (X) Sumber : Hasil kuesioner (diolah penulis)

Berdasarkan tabel 10 uji validitas variabel On Time Performance (X), semua butir pertanyaan dinyatakan valid karena setiap pearson correlation atau $\mathrm{r}$ hitung $>\mathrm{r}$ tabel, dan pada taraf signifikasi $<0,05$. Untuk $\mathrm{r}$ tabel 0,165 diperoleh dari tabel $\mathrm{r}$ statistik, dimana nilai $\mathrm{df}=\mathrm{N}$ (Jumlah responden)-2. Penulis menggunakan tingkat signifikasi untuk uji satu arah ( 1tailed ) dengan taraf signifikasi 0,05.

b. Uji Reliabilitas Variabel On Time Performance Reliability Statistics Cronbach's Alpha $\mathrm{N}$ of Items .722 16

Menurut Sekaran yang dikutip oleh Dwi Priyatno (2010): 98, reliabilitas diatas 0,7 adalah baik atau reliabel dapat dilihat berdasarkan tabel 11 uji reliabilitas variabel On Time Performance (X), semua butir pernyataan yang berjumlah 16 pernyataan dinyatakan reliabel karena cronbach's alpha berjumlah 0,722 >0,7.

\section{Analisis Hasil Penelitian Minat Beli Ulang (Variable Y)}

Penulis membuat penjabaran variable $\mathrm{Y}$ (Minat Beli Ulang) ke dalam indikator untuk membuat suatu kuesioner, dimana dapat dilihat berikut ini:

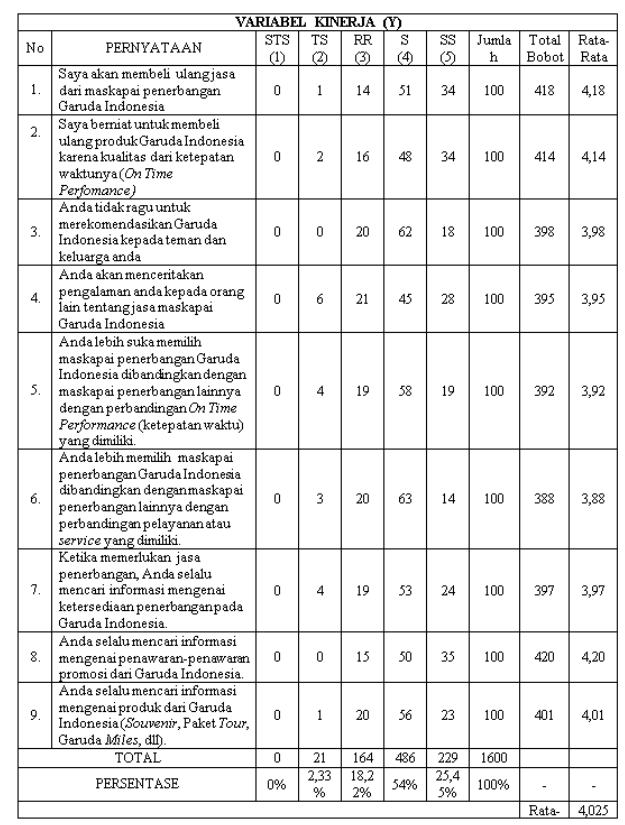

Tabel 12 Rekapitulasi Total Bobot Jawaban Kuesioner Responden Mengenai Minat Beli Ulang (Variabel Y)

Dari rekapitulasi data pada table 12 variabel Minat Beli Ulang (Y) diatas dapat dikatakan bahwa jumlah responden yang menjawab 9 butir pernyataan dari variabel Minat Beli Ulang (Y) yang memilih sangat setuju (SS) yaitu 229 responden atau sebesar 25,45, setuju (S) yaitu 486 responden atau sebesar $54 \%$, ragu-ragu (RR) yaitu 164 atau sebesar $18,22 \%$, tidak setuju (TS) yaitu 21 responden atau sebesar 2,33\%, dan sangat tidak setuju (STS) yaitu 0 responden atau sebesar $0 \%$.

Kriteria Penelitian Berdasarkan Weight Mean Scored:

\begin{tabular}{|c|c|}
\hline Interval & Kriteria \\
\hline $1,00-1,80$ & Sangat Tidak Baik \\
\hline $1,81-2,60$ & Tidak Baik \\
\hline $2,61-3,40$ & Cukup Baik \\
\hline $3,41-4,20$ & Baik \\
\hline 4,21 - 5, (19el Sun & $\begin{array}{l}\text { 3SXxitrigaderBainitk } \\
\text { er: Siregar (2012) }\end{array}$ \\
\hline
\end{tabular}


Berdasarkan tabel 13 untuk variabel Minat Beli Ulang (Y), menunjukkan bahwa rata-rata pernyataan sebesar 4,025 dengan kriteria baik.

Dengan respon rata-rata baik dari responden untuk Minat Beli Ulang (Y) pada maskapai penerbangan Garuda Indonesia, menandakan bahwa responden setuju bahwa ada keinginan atau kemauan untuk membeli ulang jasa penerbangan maskapai penerbangan Garuda Indonesia berdasarkan minta-minat yang sudah ditentukan.

\section{a. Uji Validitas Variabel Minat Beli Ulang (Y)}

Penulis melakukan uji validitas dengan bantuan software SPSS versi 21. Berikut ini merupakan hasil uji validitas dan uji reabilitas variabel Minat Beli Ulang (Y):

\begin{tabular}{|c|c|c|c|c|c|}
\hline Variabel & $\begin{array}{c}\text { Item } \\
\text { Kuesio } \\
\text { ner }\end{array}$ & $\begin{array}{c}\text { Peasson } \\
\text { Corellation } \\
\text { (r Hitung) }\end{array}$ & $\begin{array}{c}\text { Signifika } \\
\text { nsi }\end{array}$ & $\begin{array}{c}\text { rTabe } \\
\mathbf{1}\end{array}$ & $\begin{array}{c}\text { Keteranga } \\
\mathbf{n}\end{array}$ \\
\hline $\mathbf{1}$ & 0,595 & 0,000 & 0,165 & Valid \\
\cline { 2 - 6 } & $\mathbf{2}$ & 0,629 & 0,000 & 0,165 & Valid \\
\cline { 2 - 6 } & $\mathbf{3}$ & 0,578 & 0,000 & 0,165 & Valid \\
\cline { 2 - 6 } & $\mathbf{4}$ & 0,712 & 0,000 & 0,165 & Valid \\
\cline { 2 - 6 } Minat Beli \\
Ulang (Y) & $\mathbf{5}$ & 0,638 & 0,000 & 0,165 & Valid \\
\cline { 2 - 6 } & $\mathbf{6}$ & 0,583 & 0,000 & 0,165 & Valid \\
\cline { 2 - 6 } & $\mathbf{7}$ & 0,327 & 0,000 & 0,165 & Valid \\
\cline { 2 - 6 } & $\mathbf{8}$ & 0,549 & 0,000 & 0,165 & Valid \\
\cline { 2 - 6 } & $\mathbf{9}$ & 0,649 & 0,000 & 0,165 & Valid \\
\hline
\end{tabular}

Berdasarkan tabel 14 uji validitas variabel Minat Beli Ulang (Y), semua butir pertanyaan dinyatakan valid karena setiap pearson correlation atau $\mathrm{r}$ hitung $>\mathrm{r}$ tabel, dan pada taraf signifikasi $<0,05$. Untuk $r$ tabel 0,165 diperoleh dari tabel $\mathrm{r}$ statistik, dimana nilai $\mathrm{df}=\mathrm{N}$ (Jumlah responden)-2. Penulis menggunakan tingkat signifikasi untuk uji satu arah ( 1tailed) dengan taraf signifikasi 0,05.

b. Uji Reliabilitas Variabel Y Minat Beli Ulang

\begin{tabular}{l} 
Reliability Statistics \\
\begin{tabular}{|l|l|}
\hline Cronbach's Alpha & N of Items \\
\hline 757 & 9 \\
\hline
\end{tabular} \\
\hline Tabel 15 Hasil Uji Reliabilitas Variabel Minat Beli Ulang (Y)
\end{tabular}

Menurut Sekaran yang dikutip oleh Dwi Priyatno (2010): 98, reliabilitas diatas 0,7 adalah baik atau reliabel.Berdasarkan tabel 15 uji reliabilitas variabel Minat Beli Ulang (Y), semua butir pernyataan yang berjumlah
9 pernyataan dinyatakan reliabel karena cronbach's alpha berjumlah 0,757>0,7.

Analisis Pengaruh On Time Performance Terhadap Minat Beli Ulang Pada PT. Garuda Indonesia (Persero) Tbk.

Untuk mengetahui ada atau tidaknya pengaruh antara variabel $\mathrm{X}$ (On Time Performance) dengan variabel Y (Minat Beli Ulang) maka digunakan analisis kuantitatif yang menggunakan perhitungan statistik metode regresi linier sederhana, koefisien penentu dan uji hipotesis.

Dimana data-data yang menjadi perhitungan didapat dari kuesioner yang disebarkan kepada pengguna jasa penerbangan PT. Garuda Indonesia (Persero) Tbk dan diolah penulis dalam bentuk perhitungan dan dapat dihitung regresi linier sederhana, analisis koefisien determinasi atau penentu dan uji hipotesis.

1. Analisis Regresi Linear Sederhana Rumus yang digunakan menurut Sugiyono (2015:188) adalah sebagai berikut: $\mathrm{Y}=\mathrm{a}+\mathrm{b}$ $\mathrm{X}$

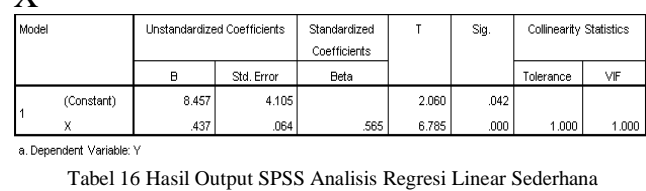

Berdasarkan hasil perhitungan melalui software IBM SPSS versi 21 diperoleh nilai a sebesar 8,457, nilai b adalah sebesar 0,437. untuk rumus persamaan regresi linear berganda dengan sebagai berikut:

$$
\mathbf{Y}=\mathbf{a}+\mathbf{b X}
$$

Maka dilihat dari hasil perhitungan melalui software IBM SPSS versi 21 sesuai 4.17, persamaan regresi linear sederhana sebagai berikut :

$$
\mathrm{Y}=\mathbf{8 , 4 5 7 + 0 , 4 3 7 \mathrm { X }}
$$

Berdasarkan hasil perhitungan yang dilakukan atas diperoleh nilai a adalah sebesar 8,457 dan nilai $b$ adalah sebesar 0,437. Nilai koefisien regresi 'atau nilai b persamaan regresi sederhana tersebut menunjukkan angka positif sebesar 0,437 yang mengandung arti bahwa setiap peningkatan On Time Performance (X) akan diikuti dengan peningkatan terhadap Minat Beli Ulang (Y) sebesar 0,437. Demikian pula 
sebaliknya, jika On Time Performance (X) mengalami penurunan 0,437 maka kelancaran pendistribusian produk juga mengalami penurunan sebesar 0,437pada nilai koefisien konstanta a atau konstanta sebesar 8,457.

\section{Analisis Koefisien Determinasi / Penentu $\left(\mathbf{r}^{2}\right)$}

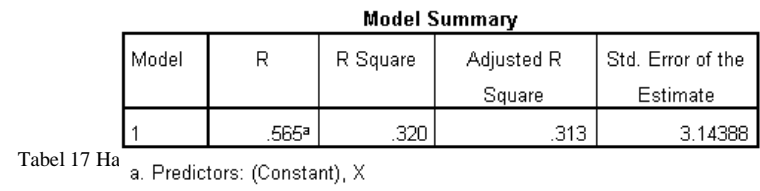

Berdasarkan hasil perhitungan melalui software IBM SPSS versi 21 yang dilihat pada tabel 17, didapatkan nilai koefisien determinasi atau penentu $\left(\mathrm{r}^{2}\right)$ sebesar 0,320 atau $32 \%$.

Dalam tesis Puspitasari (2006) mengatakan bahwa: kepuasan pelanggan berpengaruh positif terhadap minat beli ulang, dimana variable kepuasan pelanggan diukur dengan indikator kesesuaian harapan, persepsi kinerja, dan penilaian pelanggan. Pengalaman penggunaan jasa sebelumnya sangat berperan penting dalam menentukan apakah jasa tersebut dapat memberikan kepuasan bagi pelanggannya atau tidak. On Time Performance masuk di dalam variabel kesesuaian harapan, dimana konsumen akan mengharapkan penerbangan sesuai dengan jadwal. Lalu, banyak juga faktor lainnya seperti di dalam persepsi kerja yaitu pelayanan, bagasi, check-in counter. Serta variable penilaian pelanggan yang sudah dirasakan konsumen pada saat penerbangan sebelumnya. Jadi, Dapat disimpulkan bahwa pengaruh variabel On Time Performance (X) terhadap Minat Beli Ulang (Y) sebesar 32\% dan sisanya $68 \%$ merupakan faktor dari faktor-faktor lain seperti Pelayanan, Fasilitas, Pengalaman.

Menurut Sugiyono (2011:231) analisis koefisien determinasi berfungsi untuk mengetahui seberapa besar konstribusi dari variabel (X) sebagai variable independen terhadap variabel (Y) sebagai variabel dependen. Dapat dilakukan dengan perhitungan statistik dengan menggunakan koefisien determinasi $\left(K_{d}\right)$. Rumus dari koefisien determinasi sebagai berikut:

$$
\begin{aligned}
\mathrm{K}_{\mathrm{d}} & =\mathrm{r}^{2} \times 100 \% \\
& =0,320 \times 100 \% \\
& =32 \%
\end{aligned}
$$

Ket:

$\mathrm{K}_{\mathrm{d}} \quad$ : nilai koefisien determinasi

$\mathrm{r} \quad$ : nilai koefisien korelasi

\begin{tabular}{|c|c|}
\hline $\begin{array}{c}\text { Interval } \\
\text { Koefisien }\end{array}$ & Tingkat Hubungan \\
\hline $0,00-0,199$ & Sangat Rendah \\
$0,20-0,399$ & Rendah \\
$0,40-0,599$ & Sedang \\
$0,60-0,799$ & Kuat \\
$0,80-1,000$ & Sangat Kuat \\
\hline
\end{tabular}

Tabel 18 Interval Koefisien Korelas

Dari hasil yang didapat di atas maka diperoleh nilai koefisien korelasi sebesar 0,565 , yang dilihat dari table 18 bahwa nilai $\mathrm{r}$ antara 0,4 - 0,599 memiliki tingkat hubungan yang berarti sedang. Maka dapat disimpulkan bahwa variable On Time Performance (X) berkorelasi positif dengan variable Minat Beli Ulang (Y), dengan tingkat hubungan sedang.

\section{Uji Hipotesis (Uji t)}

Untuk menguji pengaruh secara parsial antara variabel On Time Performance terhadap variabel Minat Beli Ulang, penulis mengolah hasil jawaban kuesioner responden dengan menggunakan software SPSS versi 21, berikut ini merupakan hasil dari uji parsial variabel On Time Performance (X) terhadap Minat Beli Ulang (Y):

\begin{tabular}{|c|c|c|c|c|c|c|c|}
\hline No. & \multicolumn{3}{|c|}{ Variabel } & $\begin{array}{c}\mathrm{t} \\
\text { hitung }\end{array}$ & $\begin{array}{c}\text { Nilai } \\
\text { Signifikan }\end{array}$ & $\begin{array}{c}\mathrm{T} \\
\text { tabel }\end{array}$ & Keterangan \\
\hline 1. & $\begin{array}{c}\text { On Time } \\
\text { Performance }\end{array}$ & $\leftarrow$ & $\begin{array}{c}\text { Mininat } \\
\text { Transaksional }\end{array}$ & 3,573 & 0,001 & 1,660 & $>0,05 \mathrm{Ha}$ diterima \\
\hline 2. & $\begin{array}{c}\text { On Time } \\
\text { Performance }\end{array}$ & $\leftarrow$ & Minat Referensial & 4,902 & 0,000 & 1,660 & $>0,05 \mathrm{Ha}$ diterima \\
\hline 3. & $\begin{array}{c}\text { On Time } \\
\text { Performance }\end{array}$ & $\leftarrow$ & $\begin{array}{c}\text { Minat } \\
\text { Preferensial }\end{array}$ & 2,960 & 0,004 & 1,660 & $>0,05 \mathrm{Ha}$ diterima \\
\hline 4. & $\begin{array}{c}\text { On Time } \\
\text { Performance }\end{array}$ & $\leftarrow$ & Minat Eksplorasi & 6,621 & 0,000 & 1,660 & $>0,05 \mathrm{Ha}$ diterima \\
\hline \multicolumn{7}{|c|}{ Tabel 19 Hasil Temuan Pengelolaan Data }
\end{tabular}

\section{Hipotesis}

Hipotesis 1

H1a: Terdapat pengaruh On Time Performance terhadap Minat Transaksional H1o: Tidak terdapat pengaruh On Time Performance terhadap Minat Transaksional Untuk mengetahui apakah On Time Performance (X) memiliki pengaruh yang signifikan atau tidak terhadap Minat Transaksional $\left(\mathrm{Y}_{1}\right)$. Dalam uji $\mathrm{t}$, memiliki suatu perumusan hipotesis yaitu : $\mathrm{H}_{0}: \beta_{1}=0$ (tidak adanya hubungan) dan $\mathrm{H}_{\mathrm{a}}: \beta_{1} \neq 0$ (adanya pengaruh). Apabila $\mathrm{H}_{0}$ diterima 
memiliki syarat $\mathrm{t}_{\text {hitung }}<\mathrm{t}$ tabel dan $\mathrm{H}_{\mathrm{a}}$ diterima apabila $\mathrm{t}_{\text {hitung }}>\mathrm{t}$ tabel.

Berdasarkan pengujian parsial antara variabel On Time Performance (X) terhadap Minat Transaksional $\left(\mathrm{Y}_{1}\right)$, diketahui bahwa nilai $\mathrm{t}$ hitung sebesar 3,573 dengan tingkat signifikasi 0,001 dilihat berdasarkan pada tabel 19 dan $t$ tabel sebesar 1,660 dilihat dari jumlah responden 100 responden. Penulis menggunakan tingkat signifikasi 0,05 dengan syarat nilai sig $<0,05$. Untuk mencari $\mathrm{t}$ tabel, yaitu menggunakan tabel nilai distribusi $t$ dengan rumus jumlah responden (n) - 2 untuk taraf signifikasi 0,05 dan menggunakan 1 tailed. Dari data tersebut dapat diperoleh hasil, yaitu:

1) Nilai $t_{\text {hitung }} 3,573>t_{\text {tabel }} 1,660$, yang berarti $\mathrm{H}_{0}$ ditolak dan $\mathrm{H}_{\mathrm{a}}$ diterima.

2) Nilai sig $0,001<0,05$, yang berarti $\mathrm{H}_{0}$ ditolak dan $\mathrm{H}_{\mathrm{a}}$ diterima.

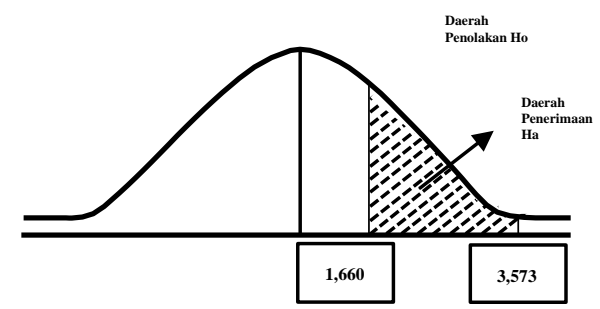

Dari gambar diatas, dinyatakan bahwa Ho ditolak dan $\mathrm{Ha}$ diterima yang diambil kesimpulan bahwa terdapat pengaruh positif antara variabel On Time Performance (X) terhadap Minat Transaksional $\left(\mathrm{Y}_{1}\right)$.

Menurut Ferdinand (2002) mengenai Minat Transaksional, kecenderungan konsumen untuk selalu membeli ulang produk yang telah dikonsumsinya. Dapat disimpulkan bahwa responden positif akan membeli ulang jasa dari maskapai penerbangan Garuda Indonesia dan berniat untuk membeli ulang produk Garuda Indonesia karena kualitas dari ketepatan waktu (On Time Performance).

Menurut Thamrin dan Francis (2012), minat beli ulang merupakan minat pembelian yang didasarkan atas pengalaman pembelian yang telah dilakukan dimasa lalu. Di dalam hipotesis ini,responden akan membeli ulang jasa maskapai penerbangan Garuda Indonesia karena kualitas dari ketepatan waktu yang sudah dialami responden dimasa lalu tersebut. Pengalaman yang sudah terjadi pada saat menggunakan jasa penerbangan Garuda Indonesia menjadi faktor konsumen ingin membeli ulang produk dari Garuda Indonesia.

Hipotesis 2

H2a: Terdapat pengaruh On Time Performance terhadap Minat Referensial H2o: Tidak terdapat pengaruh On Time Performance terhadap Minat Referensial Untuk mengetahui apakah On Time Performance (X) memiliki pengaruh yang signifikan atau tidak terhadap Minat Referensial $\left(\mathrm{Y}_{1}\right)$. Dalam uji t, memiliki suatu perumusan hipotesis yaitu : $\mathrm{H}_{0}: \beta_{1}=0$ (tidak adanya hubungan) dan $\mathrm{H}_{\mathrm{a}}: \beta_{1} \neq 0$ (adanya pengaruh). Apabila $\mathrm{H}_{0}$ diterima memiliki syarat $\mathrm{t}_{\text {hitung }}<\mathrm{t}_{\text {tabel }}$ dan $\mathrm{H}_{\mathrm{a}}$ diterima apabila $\mathrm{t}$ hitung $>$ t tabel.

Berdasarkan pengujian parsial antara variabel On Time Performance (X) terhadap Minat Referensial $\left(\mathrm{Y}_{2}\right)$, diketahui bahwa nilai $\mathrm{t}_{\text {hitung }}$ sebesar 4,902 dengan tingkat signifikasi 0,000 dilihat berdasarkan pada tabel 19 dan $\mathrm{t}$ tabel sebesar 1,660 dilihat dari jumlah responden 100 responden. Penulis menggunakan tingkat signifikasi 0,05 dengan syarat nilai sig $<0,05$. Untuk mencari $t$ tabel, yaitu menggunakan tabel nilai distribusi $t$ dengan rumus jumlah responden (n) - 2 untuk taraf signifikasi 0,05 dan menggunakan 1 tailed. Dari data tersebut dapat diperoleh hasil, yaitu :

1) Nilai $t_{\text {hitung }} 4,902>t_{\text {tabel }} 1,660$, yang berarti $\mathrm{H}_{0}$ ditolak dan $\mathrm{H}_{\mathrm{a}}$ diterima.

2) Nilai sig $0,000<0,05$, yang berarti $\mathrm{H}_{0}$ ditolak dan $\mathrm{H}_{\mathrm{a}}$ diterima.

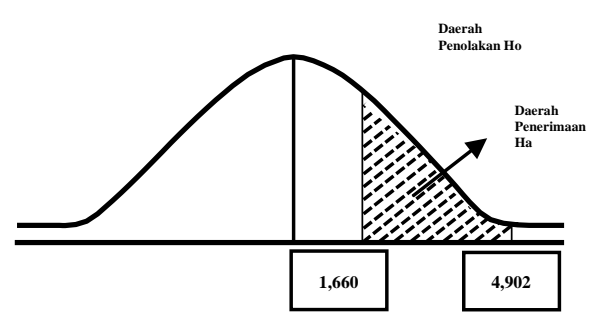

Dari gambar diatas, dinyatakan bahwa Ho ditolak dan $\mathrm{Ha}$ diterima yang diambil kesimpulan bahwa terdapat pengaruh positif antara variabel On Time Performance terhadap (X) Minat Referensial (Y).

Menurut Ferdinand (2002) mengenai Minat Referensial, yaitu kecenderungan seseorang untuk mereferensikan produk kepada orang lain. Dapat disimpulkan bahwa responden positif tidak ragu untuk merekomendasikan Garuda Indonesia kepada teman dan 
keluarga, serta akan menceritakan pengalamannya kepada orang lain tentang jasa maskapai Garuda Indonesia.

Menurut Kotler dan Keller (2009), dimana sikap konsumen akan bergantung pada dua hal yaitu, intensitas sifat negative orang lain terhadap alternative yang disukai konsumen dan motivasi konsumen untuk menuruti keinginan orang lain. Pada hipotesis ini, responden tidak ragu merekomendasikan Garuda Indonesia kepada orang lain, dimana sesuai dengan teori Kotler dan Keller ini, dimana jika ada orang lain yang merekomendasikan Garuda Indonesia dengan positif makan konsumen lainnya akan menuruti berdasarkan rekomendasi orang lain tersebut.

\section{Hipotesis 3}

H3a: Terdapat pengaruh On Time Performance terhadap Minat Preferensial H3o:

Tidak terdapat pengaruh On Time Performance terhadap Minat Preferensial Untuk mengetahui apakah On Time

Performance (X) memiliki pengaruh yang signifikan atautidak terhadap Minat

Preferensial $\left(\mathrm{Y}_{3}\right)$. Dalam uji t, memiliki suatu perumusan hipotesis yaitu : $\mathrm{H}_{0}: \beta_{1}=0$ (tidak adanya hubungan) dan $\mathrm{H}_{\mathrm{a}}: \beta_{1} \neq 0$ (adanya hubungan).

Apabila $\mathrm{H}_{0}$ diterima memiliki syarat $\mathrm{t}_{\text {hitung }}<\mathrm{t}_{\text {tabel }}$ dan $\mathrm{H}_{\mathrm{a}}$ diterima apabila $\mathrm{t}_{\text {hitung }}>\mathrm{t}$ tabel.

Berdasarkan pengujian parsial antara variabel OTP (X) terhadap Minat Preferensial $\left(\mathrm{Y}_{3}\right)$, diketahui bahwa nilai $\mathrm{t}$ hitung sebesar 2,960 dengan tingkat signifikasi 0,004 dilihat berdasarkan pada tabel 19 dan $\mathrm{t}_{\text {tabel }}$ sebesar 1,660 dilihat dari jumlah responden 100 responden. Penulis menggunakan tingkat signifikasi 0,05 dengan syarat nilai sig $<0,05$. Untuk mencari $t_{\text {tabel}}$, yaitu menggunakan tabel nilai distribusi $t$ dengan rumus jumlah responden $(n)-2$ untuk taraf signifikasi 0,05 dan menggunakan 1 tailed. Dari data tersebut dapat diperoleh hasil, yaitu:

1) Nilai $t_{\text {hitung }} 2,960>t$ tabel 1,660 , yang berarti $\mathrm{H}_{0}$ ditolak dan $\mathrm{H}_{\mathrm{a}}$ diterima.

2) Nilai sig $0,004<0,05$, yang berarti $\mathrm{H}_{0}$ ditolak dan $\mathrm{H}_{\mathrm{a}}$ diterima.

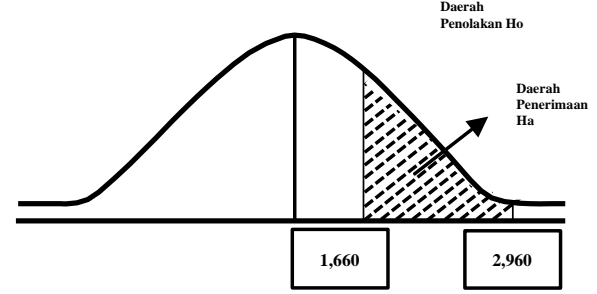

Dari gambar diatas, dinyatakan bahwa Ho ditolak dan $\mathrm{Ha}$ diterima yang diambil kesimpulan bahwa terdapat pengaruh positif antara variabel On Time Performance (X) terhadap Minat Preferensial (Y).

Menurut Ferdinand (2002) mengenai Minat Preferensial, yaitu minat yang menggambarkan perilaku seseorang yang memiliki prefrensi utama pada produk tersebut. Preferensi ini hanya dapat diganti jika terjadi sesuatu dengan produk prefrensinya. Dapat disimpulkan bahwa responden positif lebih suka memilih maskapai penerbangan Garuda Indonesia dibandingkan dengan maskapai penerbangan lainnya dengan perbandingan On Time Performance (ketepatan waktu) yang dimiliki, serta lebih memilih maskapai penerbangan Garuda Indonesia dibandingkan dengan maskapai penerbangan lainnya dengan perbandingan pelayanan atau service yang dimiliki.

Hipotesis 4

H4a: Terdapat pengaruh On Time Performance terhadap Minat Eksplorasi H4o: Tidak terdapat pengaruh On Time Performance terhadap Minat Eksplorasi Untuk mengetahui apakah On Time Performance (X) memiliki pengaruh yang signifikan atau tidak terhadap Minat Eksplorasi $\left(\mathrm{Y}_{4}\right)$. Dalam uji t, memiliki suatu perumusan hipotesis yaitu : $\mathrm{H}_{0}: \beta_{1}=0$ (tidak adanya hubungan) dan $\mathrm{H}_{\mathrm{a}}: \beta_{1} \neq 0$ (adanya hubungan). Apabila $\mathrm{H}_{0}$ diterima memiliki syarat $\mathrm{t}_{\text {hitung }}<\mathrm{t}_{\text {tabel }}$ dan $\mathrm{H}_{\mathrm{a}}$ diterima apabila $\mathrm{t}$ hitung $>\mathrm{t}$ tabel.

Berdasarkan pengujian parsial antara variabel On Time Performance (X) terhadap Minat Eksplorasi $\left(\mathrm{Y}_{4}\right)$, diketahui bahwa nilai $\mathrm{t}$ hitung sebesar 6,620 dengan tingkat signifikasi 0,000 dilihat berdasarkan pada tabel 19 dan $\mathrm{t}$ tabel sebesar 1,660 dilihat dari jumlah responden 100 responden. Penulis menggunakan tingkat signifikasi 0,05 dengan syarat nilai sig $<0,05$. Untuk mencari t tabel, 
yaitu menggunakan tabel nilai distribusi t dengan rumus jumlah responden (n) - 2 untuk taraf signifikasi 0,05 dan menggunakan

1 tailed. Dari data tersebut dapat diperoleh hasil, yaitu:

1) Nilai $t_{\text {hitung }} 6,620>t_{\text {tabel }} 1,660$, yang berarti $\mathrm{H}_{0}$ ditolak dan $\mathrm{H}_{\mathrm{a}}$ diterima.

2) Nilai sig $0,000<0,05$, yang berarti $\mathrm{H}_{0}$ ditolak dan $\mathrm{H}_{\mathrm{a}}$ diterima.

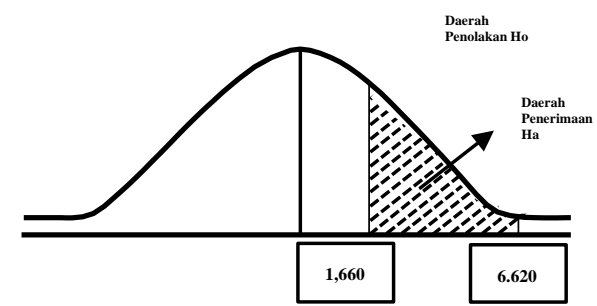

Dari gambar diatas, dinyatakan bahwa Ho ditolak dan Ha diterima yang diambil kesimpulan bahwa terdapat pengaruh positif antara variabel On Time Performance (X) terhadap Minat Eksplorasi (Y).

Menurut Ferdinand (2002) mengenai Minat Eksplorasi, minat ini menggambarkan perilaku seseorang yang selalu mencari informasi mengenai produk yang diminatinya dan mencari informasi untuk mendukung sifat-sifat positif dari produk tersebut. Dapat disimpulkan bahwah responden positif ketika memerlukan jasa penerbangan akan selalu mencari informasi mengenai ketersediaan penerbangan pada Garuda Indonesia, selalu mencari informasi mengenai penawaran- penawaran promosi dari Garuda Indonesia, dan selalu mencari informasi mengenai produk dari Garuda Indonesia (Souvenir, Paket Tour, Garuda Miles).

Pada Lucas \& Britt (2012) dalam faktor yang mempengaruhi minat beli konsumen di bagian Keyakinan (Conviction) adanya perasaan percaya diri individu terhadap kualitas, daya guna, dan keuntungan dari produk yang akan dibeli. Pada hipotesis ini, konsumen memiliki keyakinan pada produk- produk Garuda Indonesia dilihat dari responden yang selalu mencari informasi mengenai penawaran dan promosi dari Garuda Indonesia yang sudah percaya mengenai kualitas serta kuntungan dari promosi-promosi Garuda Indonesia tersebut.

\section{PENUTUP}

\section{1) Simpulan}

Berdasarkan penjelasan diatas mengenai "Pengaruh On Time Performance terhadap Minat Beli Ulang pada PT. Garuda Indonesia (Persero) Tbk." dapat disimpulkan bahwa manajemen atau program yang dilakukan maskapai penerbangan Garuda Indonesia untuk memaksimalkan kinerja dalam bidang ketepatan waktu (On Time Performance), dimana PT. Garuda Indonesia memperhatiakan dari segala bidang, yaitu: Ramp Handling, Terminal Handling, Operational Handling, Technical Problem, Eksterns. Program tersebut bertujuan untuk meningkatkan kepuasan pelanggan sehingga program dari Garuda Indonesia tersebut sudah sangat lengkap sehingga meminimalisir adanya delay atau keterlambatan.

Selanjutnya, dapat disimpulkan juga dari hasil temuan pengaruh On Time Performance pada PT. Garuda Indonesia (Persero) Tbk. Pada minat beli ulang konsumen yaitu sebesar $32 \%$ yang artinya bahwa variable $O n$ Time Performance (X) berkorelasi positif dengan variable Minat Beli Ulang (Y), dengan tingkat hubungan sedang. Karena, On Time Performance itu sendiri adalah salah satu dari berbagai faktor konsumen mengambil keputusan untuk membeli ulang jasa Garuda Indonesia. On Time Performance masuk di dalam salah satu variable kesesuaian harapan, dimana konsumen akan mengharapkan penerbangan sesuai dengan jadwal. Jadi, Dapat disimpulkan bahwa pengaruh variabel On Time Performance (X) terhadap Minat Beli Ulang (Y) sebesar 32\% dan sisanya $68 \%$ merupakan faktor dari faktor-faktor lain seperti pelayanan, bagasi, check-in counter, fasilitas, pengalaman, serta variable penilaian pelanggan yang sudah dirasakan konsumen pada saat penerbangan sebelumnya.

Dari segi On Time Performance menjadi alasan utama konsumen mempunyai minat beli ulang, dapat dilihat dari data di atas bahwa On Time Performance bukan menjadi satu-satunya alasan komsumen membeli ulang jasa penerbangan Garuda Indonesia. Walaupun berdasarkan data tingkat hubungannya baik, alasan konsumen memutuskan untuk membeli ulang jasa 
penerbangan Garuda Indonesia sebesar 32\% yang dipengaruhi oleh On Time Performance. Artinya masih terdapat aspek lain di luar On Time Performance sebesar $68 \%$ yang mempengaruhi minta beli ulang jasa penerbangan Garuda Indonesia.

\section{2) Saran}

Berdasarkan hasil penelitian secara keseluruhan dan kesimpulan yang diperoleh, maka dapat dikembangkan beberapa saran bagi pihak-pihak yang berkepentingan dalam penelitian ini. Adapun saran-saran yang dikemukakan adalah sebagai berikut:

1. Tetap mempertahankan dan bahkan mengembangkan manajemen On Time Performance dari semua aspek, yaitu: Ramp Handling, Terminal Handling, Operational Handling, Technical Problem, Eksterns. Terlebih pada aspek Eksterns (cuaca, airport security, crew pesawat yang terlambat) yang tidak bisa diduga-duga. Karena On Time Performance adalah salah satu faktor yang sulit diterapkan atau dilaksanakan oleh maskapai penerbangan yang lainnya. On Time Performance juga adalah faktor yang sangat kuat bagi konsumen mementingkan perjalanan yang sesuai jadwal atau yang mempunyai jadwal yang sudah teratur.

2. Untuk penelitian mengenai On Time Performance selanjutnya bisa difokuskan terhadap kinerja On Time Performance sehingga dapat memperluas dan lebih jelas mengenai bagaimana kinerja di bidang On Time Performance.

\section{DAFTAR PUSTAKA}

Abdullah, Thamrin dan Tantri Francis. 2012. Manajemen Pemasaran. Jakarta : PT Raja Grafindo Persada.

Annafik, AF dan M. Rahardjo. 2012. Analisis Pengaruh Kualitas Produk, Harga, Dan Daya Tarik Iklan Terhadap keputusan Sepeda Motor Yamaha (Studi Kasus Pada Konsumen Yamaha Ss Cabang Kedungmundu Semarang). Journal Of Management.

Ferdinand, A. 2002. Structural Equation Modelling dalam Penelitian Manajemen, edisi 2. Semarang: BP UDIP.

Kotler, Philip dan Keller. 2009. Manajemen Pemasaran. Edisi 13 Jilid 1 Jakarta
Lucas, DB, \& Britt, SH. 2012. Measuring Advertising Effectiveness. New York: McGraw-Hill

Mulyanto, Hadi Felix. 1999. Ground Handling dan Tata Operasi Darat. Bandung: Gramedia Pustaka Utama.

Nasr, AY. 2008. The Management Guide to Airlines Indicators, Terms, Definition and Methodology The Building Blocks for Examination of Trends and Projections. Phillips Business Information Inc.

Nasution, MN. 2015. Manajemen Transportasi. Jakarta: Ghalia Indonesia.

Prince JT, Simon DH. 2014. Do Incumbents Improve Service Quality in Response to Entry? Evidence from Airlines' On-Time Performance. Indiana University.

Priyatno, Dwi. 2010. Cara Mudah dan Cepat Melakukan Analisis Data Penelitian. Yogya: Gava Media

Puspitasari, Diana. 2006. Analisis Pengaruh Persepsi Kualitas dan Kepuasan Pelanggan Terhadap Minat Beli Ulang (Studi Kasus pada Maskapai Penerbangan Garuda Keberangkatan Semarang) [Tesis]. Semarang (SMG): Universitas Diponegoro.

Salim, HA Abas. 1993. Manajemen Transportasi. Jakarta: PT. Raja Grafindo.

Siregar, Syofian. (2012). Metode Penelitian Kuantitatif Dilengkapi Dengan Perbandingan Perhitungan Manual dan SPSS. Jakarta: Prenadamedia Group.

Sugiyono. 2012. Metode Penelitian Kuantitatif Kualitatif dan $R \& B$. Bandung: Alfabeta.

Suzuki, Yoshinori. 1999. The Relationship Between On-Time Performance and Airline Market Share: a New Approach. Department of Logistics, Operations and MIS, College of Business, Iowa State University, 300 Carver Hall, Ames, IA 50011, USA. 